UDK: 658.8:338.48-6:7/8(497.581.2 Šibenik)

Prethodno priopćenje

Primljeno 3. rujna 2020.

\title{
Potentials and Possibilities of Branding Intangible Cultural Heritage Using the Example of Šibenski botun
}

\section{IVANA SCHILDENFELD}

Edward Bernays University College, Zagreb

ivana.schildenfeld@bernays.hr

\section{STANA ODAK KRASIĆ}

VERN' University of Applied Sciences, Zagreb

stana.odak.krasic@vern.hr

The tourist market is expanding quickly and tourists are becoming more demanding and selective. Therefore, tourism requires creating an image and a brand based on an authentic identity by using innovative and enticing ideas that will result in attracting the attention of target audiences. "Šibenski botun" with its historical, social and cultural potential, as cultural heritage represents an ideal platform for the branding process and the development of cultural tourism. To begin with the branding process, it was necessary to explore the perception of the local community as one of the primary audiences. To this end, a questionnaire was used as a measuring instrument in the data collection method on a previously selected sample. The study confirmed a hypothesis that Šibenik residents were not perceiving "Šibenski botun" as the city's brand, but as an extremely important souvenir. Using three structured interviews possibilities and potentials of "Šibenski botun" have been studied for the purpose of the branding process.

Keywords: brand, branding, cultural tourism, intangible cultural heritage, Šibenski botun 


\section{Introduction}

According to the theory available in literature, we can clearly define the differences between the concepts of brand and branding: a brand is a product, service or organization that we consider in combination with its name, identity and reputation. Branding is the process of designing, planning and communicating names and identities in order to build or manage reputation (Skoko, 2009).

Place branding is a long-term process rather than a short-term campaign and designing a branding strategy and its thorough implementation takes time and effort, wisdom and patience, which will ultimately, if done properly, bring long-term benefits and overcome costs. Mihevc (2015) argues that destination reputation should be built on features that are positive, attractive, unique, sustainable and relevant to many different people around the world.

In today's globalized world, every destination, especially a tourist destination, has to contend with the competition for its market share. In order to successfully differentiate itself, it is necessary to develop a strategy that must be based on a clearly defined vision for the future based on existing resources, motivation, capabilities, intellectual capital and perception of the place. As one of the foundations of a tourist destination, intangible cultural heritage is an important element of the place branding process. It can also help develop cultural and national identity within the context of globalization.

The most common types of tourism that best represent intangible cultural heritage are cultural and event tourism, according to Bjeljac et al. (2015). Namely, part of the tourist space is also cultural heritage, which includes intangible elements, comprising cultural events, such as festivals. According to the authors, it is also necessary to emphasize those elements of intangible cultural heritage that are directly related to tangible cultural goods, such as specifically handicraft products, and cite the example of shoemaking in Serbia. In 2013, the Republic of Serbia initiated the procedure of including the skill of making opanci on the national list of the Center for Intangible Cultural Heritage of Serbia and proposed the entry of opanak on the UNESCO list of intangible cultural heritage as an endangered craft skill. Opančarstvo as a national Serbian brand, recognizable in the world, has no direct connection with tourism, except that it is part of the traditional Serbian costume, which is especially characteristic of ethnographic tourist events, and which represent the intangible cultural heritage.

The purpose of this paper was, by reviewing selected professional literature and conducted empirical research, to create assumptions and determine the possibilities and potentials for the process of branding Šibenik button as cultural heritage of the community.

The main goal of the research of this paper was to determine the perception of the local community as the primary public towards the Šibenik button as a brand of the city, and to define the souvenirs that appear in the perception of the inhabitants of Šibenik. 


\section{Intangible Cultural Heritage as an element of the Destination Brand}

The global tourist culture, which replaces traditional cultures with its standard products, diminishes the uniqueness of a tourist destination. Globalization that manipulates local culture precisely destroys those features of tourism that encourage people to travel, according to anthropologist Romana Franjić (2011). Franjić believes that the situation in Croatia is very similar because tourist destinations are becoming more related, they are starting to look like each other, so tourists are starting to look for an experience that is authentic and different. Tourism can turn natural and cultural goods, even intangibles, into economic goods. Thus, intangible traditional heritage appears in a new role as one of the foundations of a tourist destination.

The author points out that tourism can be one of the ways to preserve intangible heritage, but it must not endanger or become its purpose in any way, unless tourism encourages the holders of that heritage to preserve and further transfer it. Also, Franjić (2011) proposes, in order to preserve the intangible cultural heritage in the case of its inclusion in the tourist offer, to do the following:

- Involve the local community, i.e. holders of intangible heritage at all levels of tourist offer, from planning, through providing services to the possibility of deciding on exemption from tourist consumption of intangible heritage, because "every tourist resource does not have to be a tourist attraction" (Kušen, 2002:15 according to Franjić 2011).

- Consult experts, at an interdisciplinary level, and especially ethnologists, who have been present in a certain field for a long time, in planning, monitoring and evaluation and further research into the inclusion of intangible heritage in the tourist offer, in order to avoid unwanted consequences such as degradation or destruction of intangible heritage;

- Ensure the availability of information and continuing education of the community and those who manage the development of the community and area to become aware of certain values they include in tourism, to ensure the quality of tourism, but also to preserve intangible heritage, enabling its further survival and adaptating to new living conditions, which also ensures a better quality of life. The author especially emphasizes the need for professional education for event organizers, i.e. specially trained animators, guides, and interpreters.

In Croatia, the musical expression ojkanje is inscribed on the UNESCO list of intangible cultural heritage in need of urgent protection, and it is believed that some crafts, such as filigree, are also on the verge of extinction. By researching and valorizing intangible cultural heritage in tourism, Bjeljac and associates have come to the conclusion that the most representative elements of national cultural heritage do not necessarily have to be the most attractive for tourism. The authors believe it can be done by forming a national or local identity and brand, using a large number of intangible cultural heritage elements creating a more positive image of the destination (Bjeljac, et al., 2015).

Franjić (2011) believes that cultural resources are values that can be highlighted as the leading product of a destination and that it is the cultural heritage that distinguishes one destination from others. Heritage, continues Franjić, is the basic element used by tourist destination management to attract tourists to a destination and create a brand because creativity based on traditional intangible heritage pushes the boundaries of the mere functionality of a product. 


\section{3. Šibenski botun as an Element of the Process of Branding the City of Šibenik}

The difference between a souvenir and a brand is in the values that people recognize when they encounter certain products or services. Brand values must be such that people believe in them, that they are authentic and that they evoke a certain emotion. The values on which the Šibenik button is based are its historical, social and cultural characteristics.

Given that there aren't many records of the history of Šibenski botun, a great contribution to a chapter herein was given by ethnologist Jadran Kale who provided relevant data from articles he authored.

Šibenski botun is a round silver button made using the filigree technique that is known by its other names in Croatia as well: toka, botun, gumba, kljuni, dugme, puce, puc, puca or opuc. This establishes the local primacy of the form of Šibenski botun in the overall territorial scope from Plaško to Pljevlja, and even farther, according to ethnologist Jadran Kale (2011a).

One of the oldest historical templates for toke or botuni, used as medals for Venetians folk troop leaders in the $17^{\text {th }}$ century was the Roman phalera, originally part of equestrian gear (buckle on a war horse harness $)^{1}$. During classical antiquity military medals in the form of phalerae started to take form, normally borrowing elements from equestrian gear.

Phalerae and tokas share some common features; for example, they were never given individually, but soldiers would get several at a time. They were worn on the chest and were made of fine metal with relief embellishments. The phalerae and toke were, therefore, the forerunners of military medals. So, filigree buttons, toke worn on krožet ${ }^{2}$ under kaporan ${ }^{3}$, represent one of the memories of our warrior past from the time of the formation of what we now call folk costumes (Kale, 2011a). These buttons attracted attention and respect. While they were worn with functional weapons, they also represented another layer of armour on the chest area, writes Kale (2011b).

Not only did the button have the significance of a weapon or a military medal throughout history, but the large filigree button was a symbol of social status, both for men and women. This is because only the men capable of bearing weapons wore them on their clothing and those receiving medals for military merit. Kale points out that wearing such jewellery to show your social status had the same significance as carrying a sword or a sable, a ceremonial feature of a nobleman or a military officer.

Military organization has played a major role in widespread acceptance of toka in folk traditions, especially since the time of the Cretan War (1645 - 1669), when the Dalmatian hinterland was transformed into a long-term arena of military invasions, marching, raids and migrations. A button (based on Venetian term "toka", Dragutin Parčić's Italian-Croatian dictionary contains the word "tokalija", denoting a spruced man) was one of the gifts that the heroic commanders received from their provveditores ${ }^{4}$ in Zadar.

Ethnologist Jadran Kale (2011a) says that the heroes from the Ottoman Wars who "wove buttons around them" (using the wording of the era) did so based on where they came from and their country, the Venetian Republic at the time, moving around its territory due to the nature of their profession. Mercenaries were also among the people who moved looking for work and local Majors took a liking to their medals and distinctions, so other professional migrants - goldsmiths - made their wishes come true and started making these artefacts.

\footnotetext{
A leather contraption used for harnessing animals, saddlery 
Toke and typical Dalmatian jewellery are inseparable from other areas of goldsmith craftsmanship of the former Venetian territories, claims Kale (2011b). Dating back to the time when the concept of Dalmatia included the North Albanian coast, and the members of the Catholic population from the hinterlands bought their jewellery, a connection remained when it comes to the materials, forms and techniques of contemporary Dalmatian cities and craftsmanship centres such as Prizren ${ }^{5}$. Kale points out that the key to this connection was the political hegemony from the west coast of the Adriatic Sea (Kale, 2011b).

From the $17^{\text {th }}$ century onward, there have been archival memories of such buttons as part of ceremonial coats or vest for men, and status and ceremonial red clothing described in folk heroic poems, as the forerunner of the Šibenik folk costume. Just as lace from shirts became an individual ornament used on tablecloths and in frames, by reshaping from the classical era of folk costumes, writes Kale, so the button, toka or botun was transferred to a batača needle ${ }^{6}$ that every home had to have, at least as an adornment for the bridal crown (Kale, 2011b).

Šibenski botun is widely known to the general public as part of a men's folk costume. Here it has a practical purpose - it is used to button the waistcoat. The Šibenik region button is recognisable mostly for its filigree elements. Nowadays, the botun is becoming more and more popular as a part of women's jewellery made by Šibenik goldsmiths, craftsmen who have inherited the filigree skills, a type of craftsmanship that is slowly becoming extinct.

Today, you can buy a botun in the form of earrings, rings, pendants, tie pins, brooches, necklaces and so on. The botun is shaped as two hemispheres joined in the middle and hollow on the inside. On the outside it is decorated with thin silver threads and balls. The original botun is made of silver, is of a specific size, but nowadays it is also made of gold and aluminium, in many different sizes. The most famous ambassadors of this intangible heritage from Šibenik are definitely the members of Šibenik a Capella groups, klape, who wear folk costumes decorated with a series of ten Šibenski botuni in two rows when performing.

Taking the form of a jewellery chest, according to the idea of designer Franka Baranović and made by goldsmith Ljazer Čivljak, the Croatian National Tourist Board named Šibenski botun the most original Croatian souvenir. However, it did not catch on as a continuously produced souvenir. Together with the Šibenik cap ${ }^{7}$ and Šibenik bagatin $^{8}$, Šibenski botun is one of the most recognizable and most memorable souvenirs of Šibenik, and due to its historical, social, and cultural potential, it can also become the city's brand. Because of its aesthetic values, but also practical uses as part of jewellery for men and women, Šibenski botun is often a part of diplomatic gift-giving. The botun as a folk tradition of this part of Croatia has also taken over the task of spreading Croatian national glory to other countries.

5 City in the south of Kosovo. Centre of Craft, textile and food industries.

A clothespin, needle with a small circle on top

A cap worn by Šibenik commoners from the portrait cornice of the Šibenik Cathedral, carved in mid-15th century. Part of a folk costumes and the most famous souvenir of Šibenik. Retrieved from: http://www.Šibenik-tourism.hr/hr/suveniri (1 Feb 2018)

8 Šibenik coins from the period of the Venetian rule. Retrieved from: http://www.Šibenik-tourism.hr/hr/suveniri (1 Feb 2018) 


\section{Research Methodology}

In this research paper, the authors used the approach of several data collection methods, combining a survey questionnaire to collect data on perception, and two semi-structured interviews to collect personal views, opinions, comments and suggestions on the topic of the paper.

Considering the research hypothesis, the assumption is that the inhabitants of Šibenik do not perceive the Šibenik button as a brand of the city, and the aim of the survey questionnaire as a measuring instrument was to confirm or reject the hypothesis.

The sample of respondents was selected according to the decision of the researcher, i.e. according to the criteria of place of residence or place of origin of the sampled population. "A key feature of this type of sample is the researcher's assessment according to which he decides who can offer the best information to achieve the research objectives. The researcher examines only those people who, in his opinion, have the necessary information and are ready to share it (Tkalac Verčič, Sinčić and Pološki Vokić, 2010: 77).

The method of data collection used was CAWI - computer-assisted web interviewing, due to the greater sampling range. The survey questionnaire was distributed to 172 respondents online via the Google Forms tool and was conducted in the period from 8 to 22 January 2018.

The in-depth interview as "a relatively unstructured and extensive interview in which the examiner seeks to obtain extensive, deep and detailed answers to the questions asked (Tkalac Verčič, Sinčić and Pološki Vokić, 2010: 111) was chosen by the author as another qualitative research method of data collection. In addition to a pre-prepared reminder with topics and framework questions, the paper interviewed the director of the Šibenik Tourist Board, Dino Karađole (respondent No.1), and the Šibenik craftsman, goldsmith Ljazer Čivljak (respondent No.2), as relevant experts in practice. The in-depth interview as a very high-quality source of information served to obtain a relatively deep picture of the research topic, the attitudes of the respondents, their expectations and vision of the future, and recommendations on the possibilities and potentials of branding Šibenik button.

Access to multiple data collection methods was used in this paper, combining a questionnaire to collect data on perception, and two semi-structured interviews to collect personal opinions, attitudes, comments and suggestions on the topic of the paper.

\subsection{Research results}

The research section of this paper deals with the potentials of intangible cultural heritage and the creation of a platform for a successful branding process using the example of Šibenik's cultural heritage, Šibenski botun. The main aim of the research was to investigate the primary associations of the local community when the name of Šibenik was mentioned for the purpose of identifying Šibenik's brands and whether the respondents perceived Šibenski botun as the city's brand.

The respondent sample was selected according to the place of residence or the place of origin of the sampled population. Respondents were asked to fill in the questionnaire only if they are residents of Šibenik or originating from Šibenik.

The survey questionnaire consisted of a total of four questions, two were close-ended questions, while two were open-ended questions. A total of 172 respondents were surveyed, and only the answers by respondents who completed the entire questionnaire were analysed, i.e. the answers of 154 respondents.

Primary data obtained by own research are presented graphically for easier interpretation. 
The demographic group of questions concerned the sex of the respondents and their age. Out of 154 respondents, $84 \%$ were female, while 25 (16\%) were male.

The largest number of respondents, $39 \%$, is in the 21 - 30 age group, followed by $36 \%$ of the respondents aged 31 to 40, while only $2 \%$ of the respondents are in the age group between 16 and 20 .

The first open-ended question is shown in Diagram 1., regarding the respondents' perception of Šibenik's brands. The concept of a brand as visible identity was defined in the survey question, but also as intellectual value, emotion, association, expectation and satisfaction that is felt when a specific name is heard, or a trademark, product, service, event, or any material related to that brand is seen. Respondents were given the opportunity to give several open-ended answers.

Diagram 1. Brands of Šibenik according to the perception of the local population

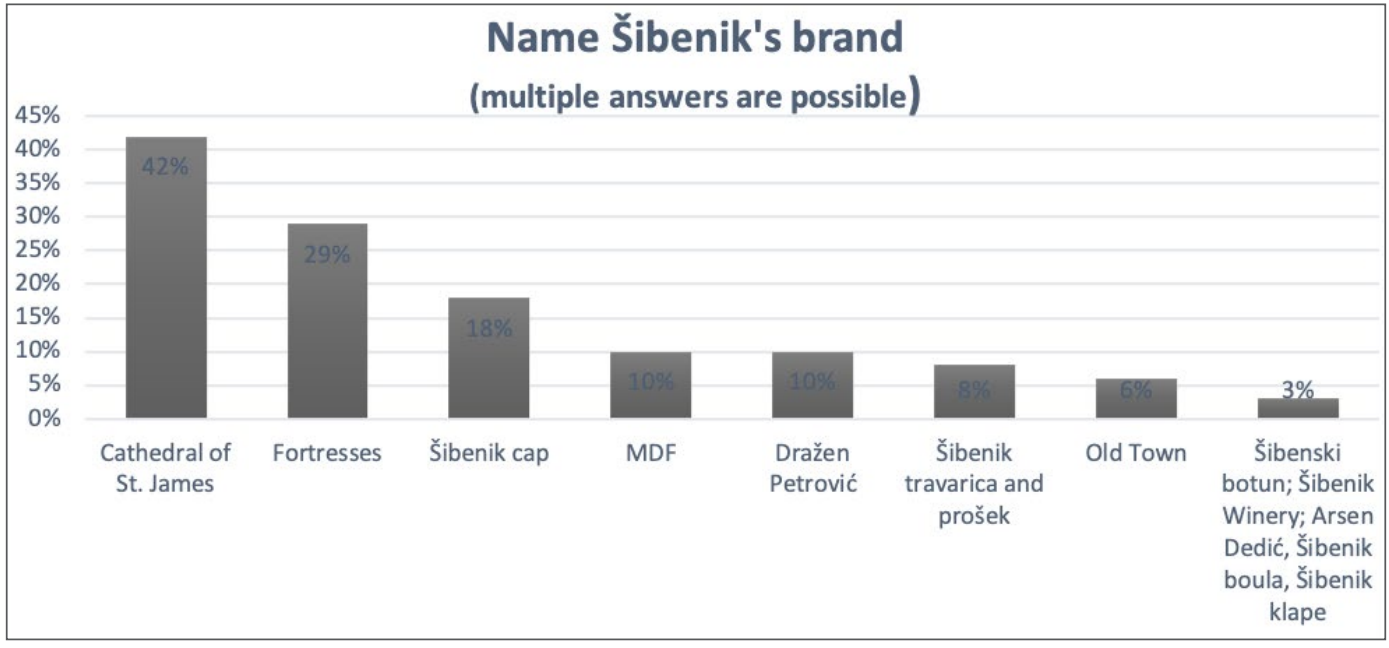

Source: Created by the author

The diagram shows that the largest number of respondents, $42 \%$, stated that the Cathedral of St. James is the most recognizable Šibenik brand, or Šibenik's trademark and symbol. Recently renovated fortification monuments, Barone Fortress, St. Michael's Fortress, as well as St. Nicholas Fortress, which was included in UNESCO's World Heritage Site list in 2017, were seen by $29 \%$ of respondents as the brand of the city. St. Michael's Fortress, seen as the city's most important cultural and historical monument, but also a place where cultural tourism is promoted by organizing different music and theatre programs on the summer stage, is an example of good practice of branding material heritage in Šibenik. Some of the respondents recognize the International Children's Festival, the Šibenik travarica (herb brandy), and notable people from Šibenik, such as Dražen Petrović, Arsen Dedić and Faust Vrančić as the brands of the city. Only eight out of 154 respondents, or $5 \%$ of Šibenik residents, perceived Šibenski botun as a brand, which would suggest that, as an object, the botun does not evoke any emotional value. The potentials and opportunities of Šibenski botun have not yet been recognized among Šibenik residents.

Another open-ended question related to the respondents' perception of Šibenik souvenirs. The aim of this question was to determine whether the subjects perceived Šibenski botun as a souvenir of the city and, if so, to what extent. Respondents were also offered the possibility of providing more than one answers. 
Diagram 2. Šibenik souvenirs as perceived by the local population

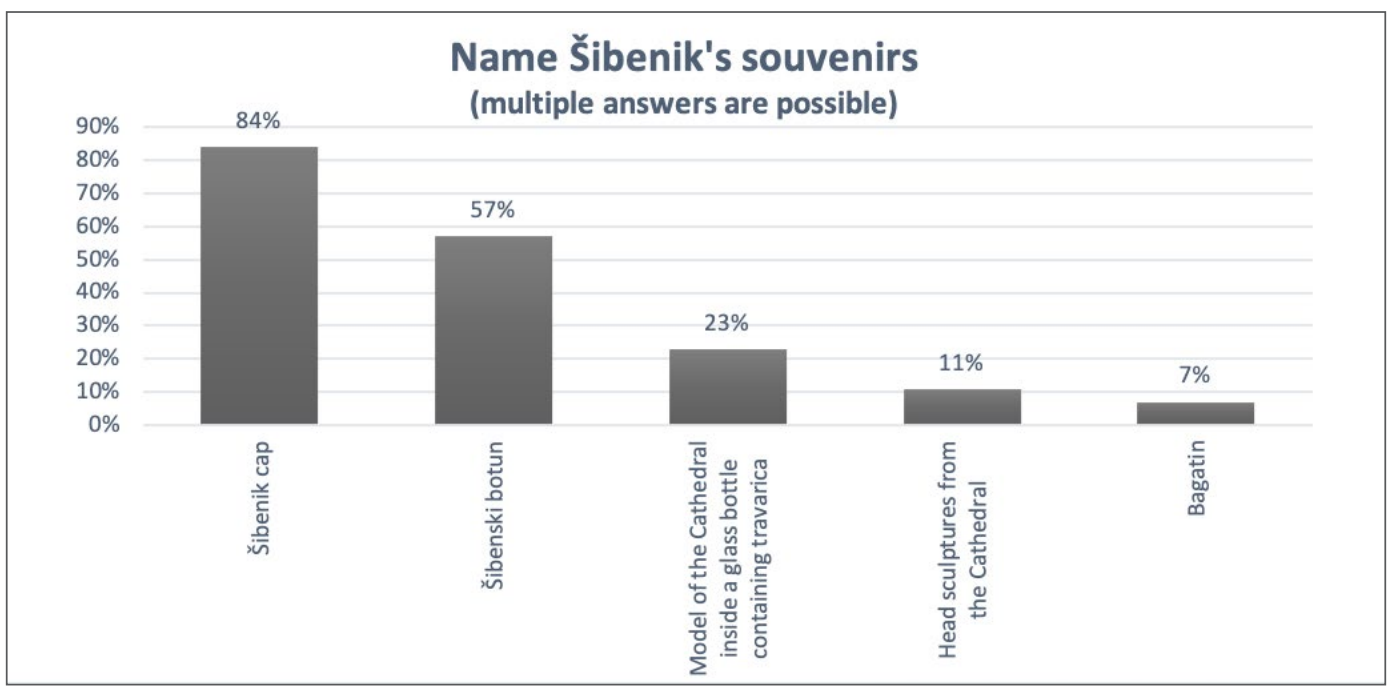

Source: Created by the author

As we can see from the Diagram 2., research has shown that most of the respondents, as many as $57 \%$ of them, perceive Šibenski botun as souvenirs of the city, while the Šibenik cap is still the most recognizable Šibenik souvenir. It is interesting to note that all the mentioned souvenirs belong to Šibenik's cultural heritage; the Šibenik cap as part of the folk costume, sculptured faces from the Cathedral, the bagatin - the previously mentioned Šibenik historic coins and a model of the cathedral inside a glass bottle containing Šibenik travarica. There is, therefore, a gap in the perception of a brand as something that conveys emotions and souvenirs as physical objects that inhabitants perceive as part of the tourist offer, but the thing they lack is exactly what makes the difference between a brand and a souvenir.

\subsection{In-depth interviews and conclusions}

Each branding process starts by defining a target group to which the values of the brand will be communicated. Given that research results show that Šibenik residents do not perceive Šibenski botun as a brand, it can be concluded that this is the primary group that the first phase of branding should be focused on. Only when the local community has perceived Šibenski botun as a brand should the campaign be directed towards the market, or towards tourists as the primary target group.

By branding Šibenski botun it is possible to tell the story of Šibenik and its history, people, traditions, customs and crafts, but also provide additional value, so that it is not only part of the tourist offer, but part of the tourist experience as well.

In the theoretical part of this paper, the chapter dealing with tourism destination differentiation, it is emphasized that the branding process involves not only the local community, but also key actors whose cohesion can significantly contribute to the process itself. Tourist boards play a key role in promoting destination offers and creating tourist destinations. One of the respondents in the indepth interview conducted on 29 January 2018 was Dino Karađole (respondent No.1), Šibenik 
Tourist Board director since 2010. The in-depth interview was aimed at finding out how Šibenik Tourist Board perceives Šibenski botun, how familiar they are with its history and whether there are any possibilities for the Tourist Board to engage in the process of branding the botun. It was also important to find out the vision of Šibenik as a tourist destination, i.e. the direction in which the city is valorised touristically, which tourists are target groups, and which factors are important for differentiating Šibenik from the competition, in order to create a general image of Šibenik Tourist Board following the process of branding the non-material cultural heritage using the example of Šibenski botun.

The second respondent in the in-depth interview conducted on 9 October 2017 was goldsmith Ljazer Čivljak (respondent No.2), one of the few Šibenik craftsmen who, using the filigree technique, creates the original Šibenski botun. In 2007 he made a jewellery box in the shape of a Sibenski botun, which won the prize for the most original souvenir in Croatia. The author of the interview wanted to find out the background of the tradition of making Šibenski botun as jewellery, the complexity of the way of making it, as well as the issues encountered by craftsmen in the promotion of jewellery, the profile of the buyers, as well as the suggestions that respondent No.2 offers for branding of Sibenski botun.

Šibenik Tourist Board director, respondent No.1, says Šibenik is finally being discovered as a tourist destination and says that this is an upward trend, though it is far from perfect. There has been a huge investment wave in the Old Town and it is extremely important to maintain high-quality service, especially of the fortresses and the Old Town as extremely important city resources.

He agrees that Šibenik should become a high-quality destination, as evidenced by the opening of new hotels, such as the new boutique hotel in the Divnić manor house, a Grade I cultural monument. However, a lot still needs to be done in Šibenik. New catering establishments and stores are opening, but all this needs to be strictly controlled to avoid mass tourism which is not compatible with the tourism vision of the city of Šibenik, says Šibenik respondent No1.

Šibenik Tourist Board supports numerous projects, programs and cultural, entertainment, humanitarian and sports events, but the financial resources are limited. Nowadays, very little money is allocated for sports and culture, which, of course, does not mean that there aren't enough possibilities and potential to make things recognizable and to give them the support they need.

Respondent No1. notes that the most important thing is to preserve the historical heritage, the historic core and prevent its devastation. His vision of Šibenik tourism is the existence of infrastructure for upper middle class and that is the basis for the tourism development strategy, based on innovative tourism. As a good example, respondent No.1 points out the revitalization of the fortresses and their connection via lifts, as well as the presentation of Šibenik heritage through "augmented reality".

Cultural heritage is an extremely important part of Šibenik tourist offer and is the basis for making Šibenik stand out among other destinations. Most people see Šibenski botun as part of the folk costume, and not many know about its historical, cultural and social importance, says respondent No.1. In 2007, Šibenik goldsmith Ljazer Čivljak made a jewellery box in the shape of a Šibenski botun, based on the concept designed by designer Franka Baranović, which won the prize for the most original souvenir in Croatia, but the story did not catch on. A big part in the story was played by members of Šibenik Craftsmen Association who initiated the idea of making an original Šibenik souvenir. Today, Šibenski botun has become an extremely popular piece of traditional jewellery, especially among women, says respondent No.1. Unfortunately, not even the Šibenik Tourist Board promotes the botun with all its possibilities. This year the Tourist Board bought various handbags, 
planners and place markers with the theme of Šibenski botun from a Zagreb company dealing with souvenir design and this is actually all there is to it regarding the botun. According to respondent No.1 the biggest problem is the price of Šibenski botun as a piece of jewellery. The city and Šibenik Tourist Board often give their guests original Šibenik souvenirs or something that is genuinely from Šibenik as diplomatic gifts, however, the price is unfortunately an important factor influencing the selection.

Respondent No.1 says that tourists currently feel that the most interesting souvenir is a stylized head from the cathedral, but most frequently they buy pendants bearing the UNESCO sign and an image of St. Nicholas Fortress.

Šibenski botun certainly has a more powerful historical story than many of Šibenik souvenirs, and is definitely not recognized or presented to the extent that it should be considering its potential; it is not at the level it should be at, says respondent No.1.

The first problem connected to the branding of Šibenski botun is certainly the fact that the local community, the inhabitants of Šibenik, is not familiar with the history of cultural heritage, botun included, so their education is necessary. He is also aware that craftsmen themselves cannot present or promote the botun. They contribute enough by making and offering them in their shops. Another problem, says respondent No.1, is the growing commercial mass production where prices are considerably lower than those of originally produced botuni, and he thinks the solution would be a certificate of excellence which would separate handmade botuni from their copies.

Traditional jewellery is becoming more and more recognized, for example, in Dubrovnik because the people there have an elite tourism tradition, so it is easier to popularize and market these products, which is not the case in Šibenik, says respondent No.1. He adds that the biggest ambassadors of Šibenski botun are the Šibenik singing association KOLO and the Šibenik a cappella groups, whose members wear it as part of their costume for performances.

A development route which Šibenik Tourist Board certainly wants to avoid is mass tourism, but balancing it is complicated. Private owners are opening an increasing number of stores and souvenir shops and so it is not easy to control the mass production. The only way it can be differentiated in mass production is the offer, especially of forgotten things; heritage, food and drink specific for the area, which requires cooperation by competent and willing people, with the utmost support of the Šibenik Tourist Board, says respondent No.1.

He is aware that a brand is something you create over the years, but it starts at a local level where it is primarily necessary to educate not only the inhabitants of a city, but also the people who are in direct contact with tourists, caterers, hotel workers and shop assistants. They need to recognise the botun as a valuable thing, full of emotions, in order to convey it not only to tourists, but also pass it on as heritage to new generations.

According to respondent No.1, in order to become a brand, a good story is required, because tourists have changed and they need more than just the sea and the sun. It is necessary to offer something more, an emotion, an experience and a story they will remember a destination for. Šibenik has a lot of potential and untold stories, especially those related to cultural heritage, and any idea that will give added value not only to the tourist offer, but also to the city itself, is welcome, says respondent No.1.

When it comes to educating the community about cultural heritage, he says he would like to point to ethnographer Jadran Kale, head of the Ethnographic Department of Šibenik City Museum, whose 
vast knowledge contributes greatly to getting to know Šibenik's heritage and Šibenski botun. It is important for the heritage to go beyond museums so that it could be recognized, primarily by the local community, and then by tourists.

An exceptionally important link in the chain and the branding process of Šibenski botun, apart from Šibenik Tourist Board, are also Šibenik craftsmen, goldsmiths who have been making traditional jewellery by using the filigree technique for many years.

Filigree as a technique in making jewellery is slowly dying, as well as many crafts not only in Croatia, but also in the region, and in the world. Craftsmen use an old technique to make objects made of silver, and less frequently, of copper and gold. The art of filigree includes delicate work in which the craftsman manually twists very thin silver wires used to form shapes, resulting in original and unique pieces. Bracelets, necklaces, rings and ornaments are the most common items filigree artists make. In 2009, suggested by the Craftsmen Association of Šibenik, the Šibenik City Council gave respondent No.2 the City of Šibenik award for his contribution to the development of family tradition of producing handicraft, and he also won an award by the Croatian National Tourist Board for the best souvenir. In addition, the latest souvenir "Bagatin", the previously mentioned medieval coin, was also taken into account. It was also revived thanks to respondent No.2 and it represents the history of the city in the best possible way.

Respondent No.2, who started working in his father's craft trade in 1965, says that his father used to make Šibenski botun as jewellery, however, it was not called Šibenski botun at the time, nor was it presented as such, it was just a piece of filigree jewellery. Later on, the story about the botun as a part of heritage started to develop, and the jewellery item eventually came to life as original Šibenik jewellery, now known as Šibenski botun, says respondent No.2. Customers, especially foreigners, come looking for the symbol of Šibenik. The story of the botun has recently been popularized and people insist on it to be from Šibenik, it is important for them for it to be genuine.

Commenting on the 2007 success of the botun as the most original Croatian souvenir, respondent No.2 points out that he was sorry that this was only partially developed, that is, the botun failed to be promoted or branded. According to respondent No.2, the botun will truly be considered a brand when it starts to be presented, when the local community gets to know its historical and cultural value and when a clear vision is set, as well as goals and people who will participate in the process are determined.

A very important detail is the Certificate of Excellence which will be used to register Šibenski botun as a traditional and artistic jewellery item, adding to its legal value, a detail that will make it stand out from commercial and mass production. He thinks that it will make the community and buyers see the botun differently as well.

He also points out the fact that there aren't enough harmonized brochures that clearly explain the historical background and the cultural value of the botun. Customers are very interested in it and want to know more, however, so far no one has made it available in writing so that people could get acquainted with its story. Some 40 years ago, this type of jewellery was not interesting to women at all, they thought it was outdated, but today it is very popular and trendy, says respondent No.2. He feels that it became popular because it was promoted by word-of-mouth and using photos on social media, so women started the trend. Also, many famous people from Šibenik have contributed to the recognition of traditional jewellery, by wearing and advertising it. 
Respondent No.2 believes that the process of branding Šibenski botun should not be left solely to the City Tourist Board, but they should be the driver, they should encourage people to participate in this process, and be the first ones to recognize the value of the botun as a piece of cultural heritage.

His suggestion is that, instead of giving cash prizes, specifically for souvenirs, the Tourist Board, the City or County, should gather all souvenirs for promotional purposes and give them as diplomatic gifts as part of protocol. He would be satisfied if the botun was popularised, given as a gift and sold more so that more and more people could find out about it. This way, the City, County or Tourist Board would give acknowledgment to the botun's value. It has not only historical and cultural, but also emotional value because the botun is considered to be a legacy passed down from generation to generation. Respondent No.2 feels that this is also a great basis and a story that tourists might be interested in.

He is aware that making the botun is an expensive process and that it takes a lot of time and effort to finalize the product. Šibenski botun is not intended for mass production, it is differentiated from other jewellery and therefore its price is somewhat higher. Buyers with higher purchasing power exist among the locals and among tourists, says respondent No.2. Most frequently, they are not interested in the price, they know exactly what they came for, and often women themselves have a vision of what they are looking for in jewellery, so they design it themselves. Foreign guests ask straight away if a product is Chinese and they ask specifically for something original and locally made, and then Šibenski botun is an ideal product to offer.

Respondent No. 2 says that he has the impression that foreign tourists know more about our cultural heritage - a Japanese TV channel recorded promotional material in his workshop and showed the whole process of making Šibenski botun. He thinks that foreigners pay even more attention to the cultural content and the offer and think that these "obsolete" methods of creating products and handwork are very appealing. Croatian TV companies have filmed the process of making botuni and bagatini several times, but it was done only for documentary purposes.

A couple of years ago, respondent No.2 adds, a crew from Dubrovnik filmed the botun production process for a company that cooperates with cruise ships. They wanted to make a destination guide for places their cruise ships dock in to familiarize tourists with the offer of a particular city.

The initiative is the most important thing, someone needs to initiate the process of branding, gather a team of experts, each of whom will have a role to play and equally contribute not only to the tourist offer, but also to the values of the city. The motive is equally important, says respondent No.2. The motive for craftsmen making traditional jewellery would be the previously mentioned certificate of traditional and artistic jewellery, showing them that they are on the right track. The motives of everyone else involved in the branding process also need to be clear.

Although research has shown that Šibenski botun is not perceived as a brand by the local population, most respondents consider it one of the most recognizable Šibenik souvenirs. 


\section{Conclusions}

Given that all the perceived souvenirs from the research are part of Šibenik's cultural heritage, but also that Šibenik invests considerable resources in restoring cultural monuments such as fortresses, it can be concluded that cultural tourism is the direction in which the city will develop in the future. The development of tourism based on the valorisation of natural and cultural heritage certainly contributes to the idea of branding Šibenski botun, but this process takes much more elaboration than the restriction or the scope of this paper permits.

Branding intangible heritage can be an important element in the process of destination branding, and marketing management is crucial for this as a prerequisite for increasing the visibility and popularity of a destination in the eyes of tourists. A successful campaign requires far more than just a visual identity. It requires a vision that will inspire the end consumer, client, tourist, or local community and that will change feelings, opinions and behaviours in relation to a particular destination.

No communication campaign will have long-term positive effects on destination promotion if the offer of the destination does not meet tourists' needs and wishes. The city's brand must provoke an experience in the eyes of the tourist and allow them to imagine and experience their ideal vacation and what they want to experience at the destination.

In the case of Šibenik, whose cultural heritage is a great resource for the diversification of the city, destination promotion has excellent bases in the existing cultural and traditional elements. Culture is a very strong and influential promotion tool because tourists are sceptical of classical marketing messages and activities, while cultural heritage is considered a valid reason to visit a destination.

Despite the increase in tourist demand, competition on the tourism market is growing every day. Every city that has a vision of becoming a tourist spot must compete with thousands of other, more or less similar destinations that are offered to tourists. In pursuit of getting a market share when it comes to the number of guests, a destination must have a clear and planned vision, identity, and strategy. Differentiating the offer and offering potential guests local uniqueness they cannot find or experience anywhere else in the world is a key to tourism development and achieving world-class standards.

With its historical, cultural and social significance, intangible heritage can become a brand that will differentiate a destination with its offer so that it simultaneously celebrates its history in a modern way, by following trends. However, people with competences, skills, imagination, ambition, and energy are needed for these destinations, so that they can initiate the spirit of creative entrepreneurship with their ideas and contribute to the development of a place. 


\section{Bibliography}

Hrvatska enciklopedija. Providur. Leksikografski zavod Miroslav Krleža. http://www.enciklopedija. $\underline{\mathrm{hr} / \text { natuknica.aspx?id=50798 }}$

Kale, J. (2009). Narodne nošnje i kultura odijevanja u sjevernoj Dalmaciji. [Doctoral dissertation University of Zagreb, Faculty of Humanities and Social Sciences].

Kale, J. (2011). Kroz šibensko ruho od anlina do žlinge, 325: Komad jadranske povijesti za dar. Šibenski list (21 Jan 2011).

Kale, J. (2011). Kroz šibensko ruho od anlina do žlinge, 342: Kraljevski botun. Šibenski list (19 May 2011).

Kale, J. (2011). Kroz šibensko ruho od anlina do žlinge, 352: Kapital obiteljskog srebra. Šibenik: Šibenski list (21 Jul 2011).

Mihevc , Z. (2015). Brendiranje gradova kao ekonomska nužnost. Tehnički glasnik, 9(2) 198-201. Morgan, N., Pritchard, A., Pride, R. (2015). Destination brands: Managing place Reputation. Clio. Skoko, B. (2009). Država kao brend; upravljanje nacionalnim identitetom. Matica Hrvatska.

Tkalac Verčić, A., Sinčić, D., \& Pološki Vokić, N. (2010). Priručnik za metodologiju istraživačkog rada: kako osmisliti, provesti i opisati znanstveno i stručno istraživanje. M.E.P. d.o.o.

\section{Webpages}

A cap worn by Šibenik commoners from the portrait cornice of the Šibenik Cathedral, carved in mid-15th century. Part of a folk costumes and the most famous souvenir of Šibenik. Retrieved from: http://www.Šibenik-tourism.hr/hr/suveniri (1 Feb 2018)

Šibenik coins from the period of the Venetian rule. Retrieved from: http://www.Šibenik-tourism.hr/ $\underline{\mathrm{hr} / \text { suveniri }}$ (1 Feb 2018)

Šibenik Craftsman Association. Šibenik City Award. http://uoŠibenik.hr/obrtnici-Šibenik-nagrade/ Šibenik/zlatarna-simon-civljak-nagrada-grada-Šibenika (1 Feb 2018) 


\section{Potencijali i mogućnosti brendiranja nematerijalne kulturne baštine na primjeru šibenskog botuna}

\section{IVANA SCHILDENFELD}

Edward Bernays Visoka škola za komunikacijski menadžment, Zagreb ivana.schildenfeld@bernays.hr

\section{STANA ODAK KRASIĆ}

Veleučilište VERN', Zagreb

stana.odak.krasic@vern.hr

Tržište turističke ponude svakodnevno raste, a turisti postaju sve zahtjevniji i izbirljiviji. Turizam stoga zahtijeva stvaranje imidža i brenda koji se temelji na stvarnom i autentičnom identitetu, korištenjem inovativnih, privlačnih ideja koje će rezultirati pozornošću ciljnih javnosti. Šibenski botun kao kulturno nasljeđe sa svojim povijesnim, društvenim i kulturnim potencijalima predstavlja idealnu platformu za proces brendiranja i razvoja kulturnog turizma. Kako bi se započeo proces brendiranja, bilo je potrebno istražiti percepciju lokalne zajednice kao jedne od primarnih javnosti. Koristeći anketni upitnik kao mjerni instrument $\mathrm{u}$ metodi prikupljanja podataka na odabranom uzorku, potvrđena je hipoteza kako stanovnici Šibenika ne percipiraju šibenski botun kao brend grada, već kao iznimno važan suvenir. Na temelju triju strukturiranih intervjua istražene su mogućnosti i potencijali šibenskog botuna za potrebe procesa brendiranja.

Ključne riječi: brend, brendiranje, kulturni turizam, nematerijalna kulturna baština, šibenski botun 